Part of Journal of Research of the National Bureau of Standards, Volume 20, May 1938

\title{
ELECTROMOTIVE FORCE OF SATURATED WESTON STANDARD CELLS CONTAINING DEUTERIUM OXIDE
}

\author{
By Langhorne H. Brickwedde and George W. Vinal
}

\begin{abstract}
Saturated Weston standard cells in which deuterium oxide is substituted for some or all of the normal water may be expected to have electromotive forces slightly different from those made with normal water. A study has been made of the characteristics of 12 cells, prepared with identical materials, except for the isotopic composition of the water. The initial samples of water contained 0.018 (normal water), 1.036, 3.121, and 6.848 mole percent of $\mathrm{D}_{2} \mathrm{O}$. The ratios of moles of $\mathrm{D}_{2} \mathrm{O}$ to $\mathrm{H}_{2} \mathrm{O}$ in the finished cells were less than in the original samples, because of dilution by the water of crystallization of the cadmium sulphate. The constancy of the electromotive force of each of the 12 cells is shown by the small average deviation of single observations, extending over several months, from the respective mean values. In no case did it exceed 0.6 microvolt. The decrease in electromotive force as a result of using the $\mathrm{D}_{2} \mathrm{O}$ amounted to 2.9 microvolts per mole percent. No significant difference was found in the temperature coefficient for the various $\mathrm{D}_{2} \mathrm{O}$ concentrations. Hysteresis measurements indicate a slight superiority for the cells containing added $\mathrm{D}_{2} \mathrm{O}$. Measurements of the internal resistance of the cells at 20 and $28^{\circ} \mathrm{C}$ indicate a ratio of $R_{20} / R_{28}=1.24$. The cells containing $\mathrm{D}_{2} \mathrm{O}$ are fully as reproducible and constant as those made with normal water, and in some respects they may be superior.
\end{abstract}

\section{CONTENTS}

I. Introduction

II. Experimental procedure

III. Experimental results

IV. Conclusions

\section{INTRODUCTION}

Saturated Weston standard cells in which deuterium oxide, $\mathrm{D}_{2} \mathrm{O}$, is substituted for some or all of the $\mathrm{H}_{2} \mathrm{O}$, may be expected to have an electromotive force slightly different from those made with normal water. The free-energy change, which determines the electromotive force of the cell, is the change accompanying the reaction:

$$
\begin{aligned}
& \mathrm{Cd}(10 \% \text { amalgam })+\mathrm{Hg}_{2} \mathrm{SO}_{4}(\mathrm{~s})+8 / 3 \mathrm{H}_{2} \mathrm{O} \text { (in satd. } \mathrm{CdSO}_{4} \text { soln.) } \\
& \leftrightarrows 2 \mathrm{Hg}(\mathrm{l})+\mathrm{CdSO}_{4} \cdot 8 / 3 \mathrm{H}_{2} \mathrm{O}(\mathrm{s})
\end{aligned}
$$

Since water enters into a part of the cell reaction involving a freeenergy change, the electromotive force developed should depend on the isotopic composition of the water present.

The three samples of deuterium oxide used in this work were prepared and standardized by the physical chemistry section of this 
Bureau. These samples were of sufficient amount to construct several cells of the same size as those which are used customarily for primary standards of electromotive force.

\section{EXPERIMENTAL PROCEDURE}

A study has been made of the characteristics of a group of 12 saturated cells constructed on July 27, 1937. These cells were prepared in the same way and with identical materials except for the isotopic content of the water used in making the solutions of cadmium sulphate. The materials were purified according to methods described in an earlier publication, ${ }^{1}$ and the cells were made in the usual manner. Four samples of water containing, respectively, 0.018 (normal water), 1.036, 3.121, and 6.848 mole percent of $\mathrm{D}_{2} \mathrm{O}^{2}$ were saturated with small $\mathrm{CdSO}_{4} \cdot 8 / 3 \mathrm{H}_{2} \mathrm{O}$ crystals. These crystals had been moistened with a small amount of $\mathrm{H}_{2} \mathrm{SO}_{4}$, so that the saturated $\mathrm{CdSO}_{4}$ solution of normal water for the control cells was $0.0226 \mathrm{~N}$ in acid. Since the crystals were well mixed and since the same ratio of crystals to water was used in all cases, each solution should be of the same acidity. In accordance with this Bureau's practice of referring to the acidity of a cell as that of the acid before saturating with neutral $\mathrm{CdSO}_{4} .8 / 3 \mathrm{H}_{2} \mathrm{O}$, these cells are designated as $0.03 \mathrm{~N}$ acid.

The ratios of moles of $\mathrm{D}_{2} \mathrm{O}$ to moles of water in the finished cells were less than in the samples initially. The dilution by the water of crystallization of the cadmium sulphate used in saturating the solution and added as excess solid to the cells is not definitely known because of lack of knowledge of the rate and extent of exchange between the $\mathrm{H}_{2} \mathrm{O}$ of the solid $\mathrm{CdSO}_{4} \cdot 8 / 3 \mathrm{H}_{2} \mathrm{O}$ crystals and the $\mathrm{D}_{2} \mathrm{O}$ of the liquid.

TABLE 1.-Dilution of deuterium oxide by water of crystallization of the cadmium sulphate

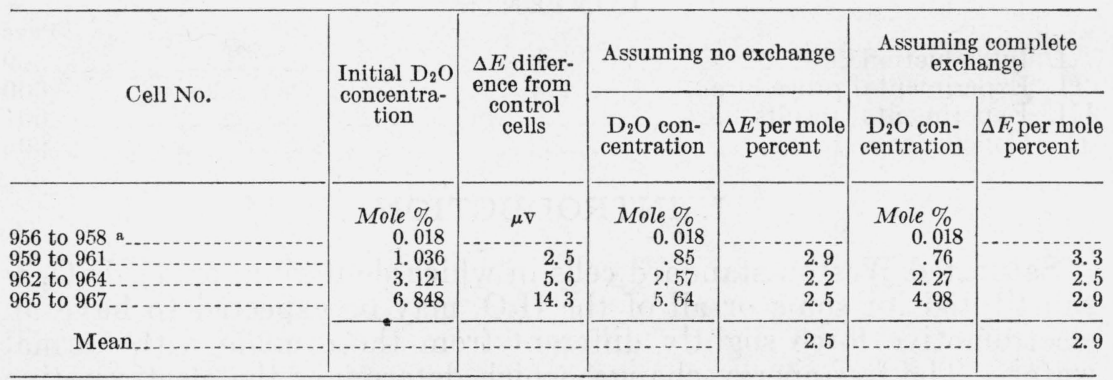

a Control cells, containing normal water.

If we assume no exchange between the liquid and crystals and attribute the dilution of the $\mathrm{D}_{2} \mathrm{O}$ to the $\mathrm{H}_{2} \mathrm{O}$ of the dissolved crystals alone, the $\mathrm{D}_{2} \mathrm{O}$ mole percentages of the water in the solutions would

\footnotetext{
1 G. W. Vinal, D. N. Craig, and L. H. Brickwedde. Trans. Electrochem. Soc. 58, 146 (1935).

2 These compositions were calculated from the densities of the samples, using the equation $N_{\mathrm{D}_{2} \mathrm{O}}$ $=9.2385 \Delta S+0.2597(\Delta S)^{2}$. In this equation, which was obtained from the data of L. G. Longsworth, J. Am. Chem. Soc. 59, 1483 (1937), by least-square computation, $N_{\mathrm{D}_{2} \mathrm{O}}$ is the mole fraction of deuterium oxide and

$$
\Delta S \text { is } d_{25}^{25}-1=\frac{d^{25}}{0.99705_{5}}-1 \text {, }
$$

in which $0.99705_{5}$ is the density, $d_{t}^{25}$, of $\mathrm{D}_{2} \mathrm{O}$-free water.
} 
be $0.018,0.85,2.57$, and 5.64 . If , on the other hand, we assume that the $\mathrm{H}_{2} \mathrm{O}$ of the solid entered into an exchange with the liquid and came to an equilibrium such that the $\mathrm{D}_{2} \mathrm{O} / \mathrm{H}_{2} \mathrm{O}$ ratio in the crystals is the same as in the solution, the mole percentages of $\mathrm{D}_{2} \mathrm{O}$ in the solutions would be $0.018,0.76,2.27$, and 4.98. The hydrogen added by the $\mathrm{H}_{2} \mathrm{SO}_{4}$ may be neglected since, in the most concentrated $\mathrm{D}_{2} \mathrm{O}$ sample, it reduced the concentration of $\mathrm{D}_{2} \mathrm{O}$ by only 0.002 mole percent.

In table 1 the mole percentages of the original samples are compared with the percentages in the finished cells on the assumptions of no exchange and complete exchange in the crystals. The difference in results based on these assumptions is of little importance since the variations in $\Delta E$ per mole percent are within the limits of scattering of the values in the various groups. From the standpoint of the present work it is immaterial, therefore, whether the exchange is complete, except as the constancy of electromotive force over a long period of time may be involved. In this paper we have assumed that the second of the above alternatives is correct and the mole percentages of $\mathrm{D}_{2} \mathrm{O}$ in tables 2 to 5 are expressed on this basis. In continuing the work, however, according to plans for constructing cells containing much higher percentages of $\mathrm{D}_{2} \mathrm{O}$, this matter will become of increasing importance and a more definite answer, based on experimental results, is to be expected.

Another uncertainty in estimating the actual concentration of $\mathrm{D}_{2} \mathrm{O}$ in the finished cells arises from the possible partial dehydration of the cadmium sulphate crystals on exposure to the air prior to using them for preparing the saturated solutions. Partial dehydration of the crystals would result in less dilution of the $\mathrm{D}_{2} \mathrm{O}$ than is shown in table 1 , but the uncertainty in the concentration would hardly be great enough to affect $\Delta E$ per mole percent by an amount large enough to be significant.

\section{EXPERIMENTAL RESULTS}

Repeated measurements of the electromotive force at $20^{\circ} \mathrm{C}$ for each cell are given in table 2. The constancy of the electromotive force of each of the 12 cells is shown by the small average deviation of single observations given in the last column. In no case is the average deviation more than 0.6 microvolt. The scattering of the mean values of individual cells in their respective subgroups is not more than 1.4 microvolts. The constancy and reproducibility of the cells, as indicated by the close agreement of the electromotive force values for each isotopic concentration, are important indications of the validity of the effect of the $\mathrm{D}_{2} \mathrm{O}$.

The mean electromotive force at $20^{\circ} \mathrm{C}$ of each subgroup is plotted in figure 1 with respect to the $\mathrm{D}_{2} \mathrm{O}$ mole percent of the water in the saturated solution. The relation of electromotive force to the $\mathrm{D}_{2} \mathrm{O}$ content is evidently linear within the range of the present work. The slope of the line indicates a decrease of electromotive force amounting to 2.9 microvolts per mole percent. ${ }^{3}$

The electromotive forces at 20 and $28^{\circ} \mathrm{C}$ are compared in table 3 . No significant difference was found in the temperature coefficients for

${ }^{3}$ In contrast with our results, Yoneda reported to the Comité Consultatif d'Electricité, 1937, a decrease of 27 microvolts for $1 / 50$ percent of $\mathrm{D}_{2} \mathrm{O}$. His results on three cells will probably be published in volume 18 of the Procès Verbaux, Comité International des Poids et Mesures. 
the various $\mathrm{D}_{2} \mathrm{O}$ concentrations. The mean change in electromotive force going from 28 to $20^{\circ} \mathrm{C}, 374.0$ microvolts, lies between the value

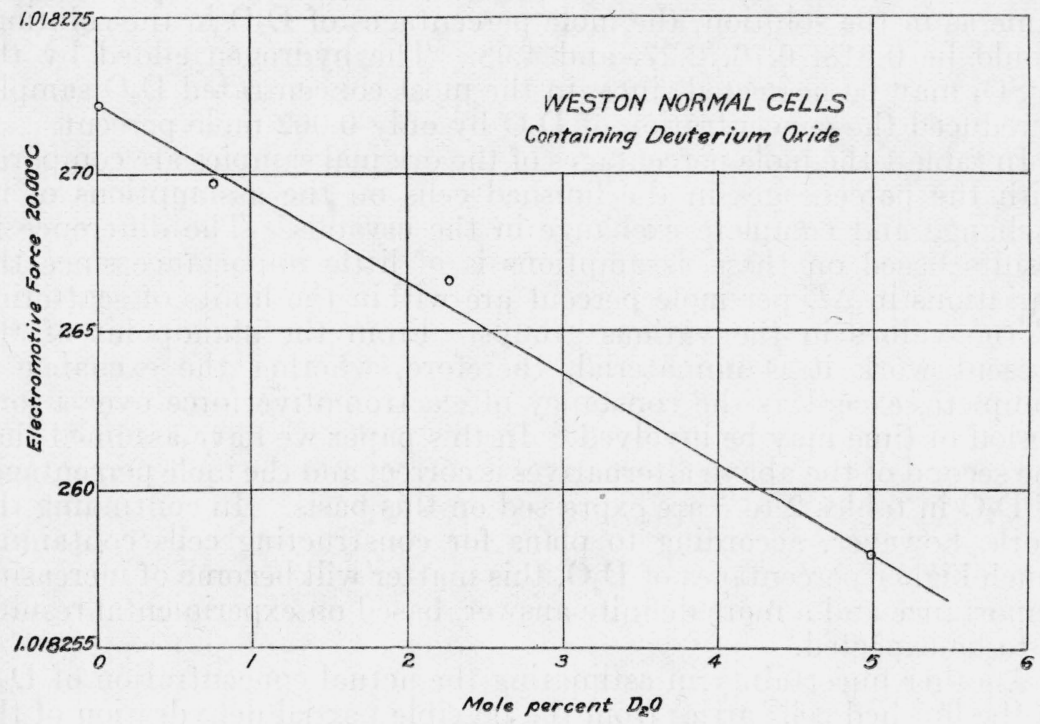

Figure 1.-Relation of electromotive force to mole percent of $\mathrm{D}_{2} \mathrm{O}$

380.5 calculated from the international temperature formula ${ }^{4}$ and 370.1 calculated from the formula of Vigoureux and Watts. ${ }^{5}$

4 Report of London Conference on Electrical Units and Standards, schedule C (1908).

$\checkmark$ Proc. Phys. Soc. (London) 45, 172 (1933). 
TABLE 2.-Electromotive force of individual cells at $20.00^{\circ} \mathrm{C}$

\begin{tabular}{|c|c|c|c|c|c|c|c|c|c|c|c|c|}
\hline \multirow{2}{*}{ Cell!no. } & \multirow{2}{*}{$\begin{array}{l}\text { Mole } \\
\text { percent } \\
\text { of } \mathrm{D}_{2} \mathrm{O}\end{array}$} & \multicolumn{10}{|c|}{ International volts; measurements made during September-November 1937} & \multirow{2}{*}{$\begin{array}{c}\text { Average } \\
\text { devia- } \\
\text { tion of } \\
\text { single } \\
\text { observa- } \\
\text { tions }\end{array}$} \\
\hline & & Sept. 9 & Sept. 15 & Sept. 23 & Oct. 2 & Oct. 8 & Oct. 18 & Oct. 28 & Nov. 15 & Nov. 19 & Mean & \\
\hline $\begin{array}{l}956 \\
957 \\
958\end{array}$ & $\begin{array}{r}0.018 \\
.018 \\
.018 \\
\end{array}$ & $\begin{array}{r}1.018272_{8} \\
70_{0} \\
71_{0} \\
\end{array}$ & $\begin{array}{r}1.018272_{7} \\
72_{4} \\
72_{4}\end{array}$ & $\begin{array}{r}1.018272_{3} \\
72_{4} \\
72_{1} \\
\end{array}$ & $\begin{array}{r}1.018272_{\theta} \\
72_{2} \\
71_{6}\end{array}$ & $\begin{array}{r}1.018272_{1} \\
71_{9} \\
71_{5}\end{array}$ & $\begin{array}{r}1.018272_{2} \\
71_{7} \\
71_{2}\end{array}$ & $\begin{array}{r}1.018273_{5} \\
72_{7} \\
72_{5}\end{array}$ & $\begin{array}{r}1.018273_{0} \\
727 \\
71_{4}\end{array}$ & $\begin{array}{r}\text { 1. } 018273_{2} \\
725 \\
72_{2}\end{array}$ & $\begin{array}{r}1.0182728 \\
72_{1} \\
71_{8}\end{array}$ & $\begin{array}{r}\mu \nu \\
0.4 \\
.6 \\
.5\end{array}$ \\
\hline Mean.- & (n)............. & $71_{3}$ & $72_{5}$ & $72_{3}$ & $72_{2}$ & $71_{8}$ & $71_{7}$ & $72_{\theta}$ & $72_{4}$ & 728 & $72_{2}$ & $-\ldots$ \\
\hline 969010 & $\begin{array}{r}0.76 \\
.76 \\
.76 \\
\end{array}$ & $\begin{array}{l}69_{1} \\
71_{0} \\
70_{7} \\
\end{array}$ & $\begin{array}{l}68_{4} \\
70_{7} \\
707\end{array}$ & $\begin{array}{l}69_{3} \\
708 \\
71_{1} \\
\end{array}$ & $\begin{array}{l}69_{3} \\
68_{9} \\
70_{3}\end{array}$ & $\begin{array}{l}68_{1} \\
69_{9} \\
68_{8} \\
\end{array}$ & $\begin{array}{l}68_{0} \\
700 \\
69_{6} \\
\end{array}$ & $\begin{array}{l}69_{1} \\
70_{6} \\
69_{0} \\
\end{array}$ & $\begin{array}{l}69_{0} \\
70_{5} \\
69_{8}\end{array}$ & $\begin{array}{l}69_{2} \\
70_{2} \\
69_{3} \\
\end{array}$ & $\begin{array}{l}68_{0} \\
70_{3} \\
70_{0}\end{array}$ & $\begin{array}{r}0.3 \\
.5 \\
.6\end{array}$ \\
\hline Mean.. & -............ & $70_{3}$ & $69_{0}$ & $70_{4}$ & $69_{5}$ & 689 & $69_{5}$ & $69_{9}$ & $69_{8}$ & $69_{6}$ & $69_{7}$ & -........... \\
\hline $\begin{array}{l}962 \\
963-\ldots 4\end{array}$ & $\begin{array}{l}2.27 \\
2.27 \\
2.27\end{array}$ & $\begin{array}{l}66_{5} \\
66_{8} \\
66_{8} \\
\end{array}$ & $\begin{array}{l}66_{4} \\
66_{5} \\
67_{6}\end{array}$ & $\begin{array}{l}67_{0} \\
67_{6} \\
685\end{array}$ & $\begin{array}{l}667 \\
66_{2} \\
67_{1}\end{array}$ & $\begin{array}{l}65_{9} \\
65_{3} \\
66_{3}\end{array}$ & $\begin{array}{l}65_{8} \\
66_{3} \\
66_{0}\end{array}$ & $\begin{array}{l}660 \\
660 \\
670\end{array}$ & $\begin{array}{l}66_{0} \\
66_{0} \\
670\end{array}$ & $\begin{array}{l}66_{1} \\
66_{8} \\
66_{0}\end{array}$ & $\begin{array}{l}66_{3} \\
66_{5} \\
66_{6}\end{array}$ & $\begin{array}{r}0.3 \\
.4 \\
.6\end{array}$ \\
\hline Mean.. & - & $66_{7}$ & $66_{8}$ & 677 & $66_{7}$ & $65_{8}$ & $66_{0}$ & $66_{3}$ & $66_{3}$ & $66_{3}$ & $66_{6}$ & - n \\
\hline 9666 & $\begin{array}{l}4.98 \\
4.98 \\
4.98 \\
\end{array}$ & $\begin{array}{l}588 \\
56_{7} \\
57_{2} \\
\end{array}$ & $\begin{array}{l}58_{7} \\
57_{2} \\
58_{8} \\
\end{array}$ & $\begin{array}{l}584 \\
584 \\
59_{4} \\
\end{array}$ & $\begin{array}{l}58_{2} \\
57_{6} \\
58_{6} \\
\end{array}$ & $\begin{array}{l}57_{2} \\
57_{0} \\
58_{0} \\
\end{array}$ & $\begin{array}{l}57_{9} \\
57_{1} \\
57_{2} \\
\end{array}$ & $\begin{array}{l}580 \\
578 \\
580 \\
\end{array}$ & $\begin{array}{l}57_{0} \\
57_{2} \\
58_{2}\end{array}$ & $\begin{array}{l}58_{2} \\
57_{2} \\
58_{8} \\
\end{array}$ & $\begin{array}{l}58_{1} \\
57_{4} \\
58_{2} \\
\end{array}$ & $\begin{array}{r}0.4 \\
.4 \\
.6 \\
\end{array}$ \\
\hline Mean... & - & $57 \mathrm{e}$ & $58_{3}$ & $58_{7}$ & $58_{1}$ & 574 & $57_{4}$ & 578 & 578 & 580 & 578 & \\
\hline
\end{tabular}


TABLE 3.-Change in electromotive force with temperature

\begin{tabular}{|c|c|c|c|c|c|}
\hline Cell No. & $\begin{array}{l}\text { Mole per- } \\
\text { cent of } \mathrm{D}_{2} \mathrm{O}\end{array}$ & $\left|\begin{array}{c}\text { Emf at } 28.00^{\circ} \\
\mathrm{C} \text { (mean } \\
\text { values) }\end{array}\right|$ & $\left|\begin{array}{c}\mathrm{Emf} \text { at } 20.00^{\circ} \\
\text { values) }\end{array}\right|$ & Difference & $\begin{array}{l}\text { Mean differ- } \\
\text { ence }\end{array}$ \\
\hline $\begin{array}{l}956 \\
957 \\
958\end{array}$ & $\begin{array}{r}0.018 \\
.018 \\
.018\end{array}$ & $\begin{array}{r}\mathrm{V} \\
\text { 1. } 017899_{1} \\
97_{5} \\
97_{6}\end{array}$ & $\begin{array}{r}\mathrm{v} \\
\text { 1. } 018272_{8} \\
72_{1} \\
71_{8}\end{array}$ & $\begin{array}{r}\mu \mathrm{V} \\
373.7 \\
374.6 \\
374.2\end{array}$ & 374.2 \\
\hline $959 \ldots 0$. & $\begin{array}{l}.76 \\
.76 \\
.76\end{array}$ & $\begin{array}{l}95_{1} \\
95_{8} \\
96_{5}\end{array}$ & $\begin{array}{l}68_{9} \\
70_{3} \\
70_{0}\end{array}$ & $\begin{array}{l}373.8 \\
374.5 \\
373.5\end{array}$ & 373.9 \\
\hline 962 & $\begin{array}{l}2.27 \\
2.27 \\
2.27\end{array}$ & $\begin{array}{l}92_{8} \\
91_{8} \\
92_{5}\end{array}$ & $\begin{array}{l}663 \\
665 \\
669\end{array}$ & $\begin{array}{l}373.5 \\
374.7 \\
374.4\end{array}$ & 374.2 \\
\hline $\begin{array}{l}965 \\
966 \\
967\end{array}$ & $\begin{array}{l}4.98 \\
4.98 \\
4.98\end{array}$ & $\begin{array}{l}84_{4} \\
83_{8} \\
84_{3}\end{array}$ & $\begin{array}{l}58_{1} \\
57_{4} \\
58_{2}\end{array}$ & $\begin{array}{l}373.7 \\
373.6 \\
373.9\end{array}$ & 373.7 \\
\hline
\end{tabular}

The results of measurements of the hysteresis of these cells are shown in table 4 . In the first test, the cells were moved from a bath at $20^{\circ} \mathrm{C}$ to another at $28^{\circ} \mathrm{C}$. The electromotive forces were measured after 2 hours in the $28^{\circ}$ bath and compared with the mean of the equilibrium values subsequently observed at that temperature. In the second test, the cells were transferred back to the $20^{\circ}$ bath and again measurements made after 2 hours at the new temperature were compared with the mean of the equilibrium values at $20^{\circ} \mathrm{C}$. The hysteresis is somewhat less for cells containing added $\mathrm{D}_{2} \mathrm{O}$ than for the cells made with normal water.

The internal resistances of the cells at 20 and $28^{\circ} \mathrm{C}$ and the ratio of the values at the two temperatures are shown in table 5 . The internal resistances, $R$, were calculated from the relation, $R=\frac{E-E^{\prime}}{E^{\prime}} \times 10^{7}$, where $E$ is the electromotive force and $E^{\prime}$ the terminal voltage observed when the cell was discharging through an external resistance of $10^{7} \mathrm{ohms}$.

TABLE 4.-Hysteresis measurements 20 to 28 to $20^{\circ} \mathrm{C}$

[The cells were measured 2 hours after abruptly changing the temperature $8^{\circ} \mathrm{C}$.]

\begin{tabular}{|c|c|c|c|c|c|c|c|}
\hline \multirow{2}{*}{ Cell No. } & \multirow{2}{*}{$\begin{array}{c}\text { Mole per- } \\
\text { cent of } \\
\mathrm{D}_{2} \mathrm{O}\end{array}$} & \multicolumn{3}{|c|}{20 to $28^{\circ} \mathrm{C}$} & \multicolumn{3}{|c|}{28 to $20^{\circ} \mathrm{C}$} \\
\hline & & $\begin{array}{l}\text { Emf } 2 \text { hr } \\
\text { after } \\
\text { change }\end{array}$ & $\begin{array}{l}\text { Equilib- } \\
\text { rium emf } \\
\text { at } 28^{\circ}\end{array}$ & $\begin{array}{l}\text { Differ- } \\
\text { ence }\end{array}$ & $\begin{array}{l}\text { Emf } 2 \mathrm{hr} \\
\text { after } \\
\text { change }\end{array}$ & $\begin{array}{l}\text { Equilib- } \\
\text { rium emf } \\
\text { at } 20^{\circ}\end{array}$ & $\begin{array}{l}\text { Differ- } \\
\text { ence }\end{array}$ \\
\hline $\begin{array}{l}956 \\
957 \\
958\end{array}$ & $\begin{array}{r}0.018 \\
.018 \\
.018 \\
\end{array}$ & $\begin{array}{r}\mathrm{v} \\
\text { 1. } 017899_{7} \\
900_{0} \\
899_{6} \\
\end{array}$ & $\begin{array}{r}\mathrm{V} \\
\text { 1. } 017899_{1} \\
897_{5} \\
897_{6} \\
\end{array}$ & $\begin{array}{l}\mu v \\
+0.6 \\
+2.5 \\
+2.0\end{array}$ & $\begin{array}{r}\mathrm{v} \\
\text { 1. } 018268_{1} \\
256 \mathrm{~s} \\
259_{0} \\
\end{array}$ & $\begin{array}{r}\mathrm{v} \\
\text { 1. } 018272_{8} \\
272_{1} \\
271_{8}\end{array}$ & $\begin{array}{r}\mu \nabla \\
-4.7 \\
-15.3 \\
-12.8\end{array}$ \\
\hline Mean & $\ldots \ldots$ & $\begin{array}{ll}\ldots \ldots \\
\end{array}$ & - & +1.7 & - . & -.......... & -10.9 \\
\hline $\begin{array}{l}959 \ldots \\
960 \ldots \\
961 \ldots\end{array}$ & $\begin{array}{r}0.76 \\
.76 \\
.76 \\
\end{array}$ & $\begin{array}{l}896_{3} \\
896_{0} \\
895_{7} \\
\end{array}$ & $\begin{array}{l}895_{1} \\
895_{8} \\
896_{5} \\
\end{array}$ & $\begin{array}{r}+1.2 \\
+0.2 \\
-.8\end{array}$ & $\begin{array}{l}266_{3} \\
269_{0} \\
269_{3} \\
\end{array}$ & $\begin{array}{l}268_{9} \\
270_{3} \\
270_{0} \\
\end{array}$ & $\begin{array}{l}-2.6 \\
-1.3 \\
-0.7\end{array}$ \\
\hline Mean.. & $\ldots . . . .$. & $\cdots$ & ........... & +0.2 & ...... & - & -1.5 \\
\hline $\begin{array}{l}962 \\
963 \\
964\end{array}$ & $\begin{array}{l}2.27 \\
2.27 \\
2.27\end{array}$ & $\begin{array}{l}894_{0} \\
890_{6} \\
892_{0} \\
\end{array}$ & $\begin{array}{l}892_{8} \\
891_{8} \\
892_{5} \\
\end{array}$ & $\begin{array}{l}+1.2 \\
-1.2 \\
-0.5 \\
\end{array}$ & $\begin{array}{l}2647 \\
262_{0} \\
2633_{3} \\
\end{array}$ & $\begin{array}{l}266_{3} \\
266_{5} \\
266_{9} \\
\end{array}$ & $\begin{array}{l}-1.6 \\
-4.5 \\
-3.6 \\
\end{array}$ \\
\hline Mean. & - & - & …… & -0.2 & ……n. & (n......... & -3.2 \\
\hline $\begin{array}{l}965 \ldots \\
966 \ldots \\
967 \ldots\end{array}$ & $\begin{array}{l}4.98 \\
4.98 \\
4.98\end{array}$ & $\begin{array}{l}885_{5} \\
884_{3} \\
885_{0}\end{array}$ & $\begin{array}{l}884_{4} \\
883_{8} \\
884_{3}\end{array}$ & $\begin{array}{r}+1.1 \\
+0.5 \\
+.7\end{array}$ & $\begin{array}{l}256_{8} \\
255_{3} \\
256_{0}\end{array}$ & $\begin{array}{l}258_{1} \\
257_{4} \\
258_{2}\end{array}$ & $\begin{array}{l}-1.3 \\
-2.1 \\
-2.2\end{array}$ \\
\hline Mean & - & $\ldots$ & $\ldots$ & +0.8 & $\ldots$ & $\ldots$ & -1.9 \\
\hline
\end{tabular}


TABLE 5.-Internal resistance of the cells

\begin{tabular}{|c|c|c|c|c|c|}
\hline \multirow{2}{*}{ Cell No. } & \multirow{2}{*}{$\begin{array}{l}\text { Mole per- } \\
\text { cent } \mathrm{D}_{2} \mathrm{O}\end{array}$} & \multicolumn{2}{|c|}{ Resistance } & \multirow{2}{*}{$\begin{array}{c}\text { Ratio } \\
R_{20} / R_{28}\end{array}$} & \multirow{2}{*}{$\begin{array}{c}\text { Mean ratio } \\
R_{20} / R_{28}\end{array}$} \\
\hline & & $20.00^{\circ} \mathrm{C}$ & $28.00^{\circ} \mathrm{C}$ & & \\
\hline $\begin{array}{l}956-\ldots \ldots . \\
957-\ldots . . . \\
958 \ldots\end{array}$ & $\begin{array}{r}0.018 \\
.018 \\
.018\end{array}$ & $\begin{array}{r}\text { Ohms } \\
\begin{array}{r}758 \\
737 \\
673\end{array}\end{array}$ & $\begin{array}{r}\text { Ohms } \\
602 \\
594 \\
539\end{array}$ & $\begin{array}{l}\text { 1. } 259 \\
\text { 1. } 241 \\
1.249\end{array}$ & 1. 250 \\
\hline $\begin{array}{l}959 \ldots \ldots \ldots \\
960 \ldots \\
961 \ldots\end{array}$ & $\begin{array}{l}.76 \\
.76 \\
.76\end{array}$ & $\begin{array}{l}839 \\
727 \\
816\end{array}$ & $\begin{array}{l}679 \\
588 \\
654\end{array}$ & $\begin{array}{l}\text { 1. } 236 \\
1.236 \\
1.248\end{array}$ & 1. 240 \\
\hline $\begin{array}{l}962 \\
963- \\
964 \ldots \\
\end{array}$ & $\begin{array}{l}2.27 \\
2.27 \\
2.27\end{array}$ & $\begin{array}{l}845 \\
799 \\
825\end{array}$ & $\begin{array}{l}682 \\
640 \\
666\end{array}$ & $\begin{array}{l}\text { 1. } 238 \\
1.248 \\
1.238\end{array}$ & 1. 241 \\
\hline $\begin{array}{l}965 \\
966 \\
967\end{array}$ & $\begin{array}{l}4.98 \\
4.98 \\
4.98\end{array}$ & $\begin{array}{l}805 \\
800 \\
769\end{array}$ & $\begin{array}{l}655 \\
645 \\
624\end{array}$ & $\begin{array}{l}\text { 1. } 228 \\
1.240 \\
1.232\end{array}$ & 1. 233 \\
\hline
\end{tabular}

\section{CONCLUSIONS}

Aside from the theoretical interest in the effect of deuterium oxide on the electromotive force of the cells, there are practical reasons for continuing the investigation. The results given in this paper indicate that the cells containing $\mathrm{D}_{2} \mathrm{O}$ are fully as reproducible and constant as those made with normal water. With respect to hysteresis they may be superior. Observations over a longer period of time are needed to determine whether the cells are less subject to the troublesome formation of gas over the amalgam terminal. We believe the results so far obtained are sufficiently promising to justify extending the work to cover a wider range of concentrations of the deuterium oxide.

The authors thank Dr. E. R. Smith, who furnished the deuterium oxide, for helpful suggestions and in particular for standardizing the samples.

Washington, December 23, 1937.

[Author's Note.-Because of the time which has elapsed since the manuscript of this paper was completed, it is desirable to state that subsequent measurements on these cells show them to maintain substantially the same relative differences. Slight increases in electromotive force have been observed in all cells, but the average increase for those made with ordinary water, 2.3 microvolts, exceeds that of the other cells, 1.7 microvolts, which argues against the likelihood of long continued exchange of $\mathrm{D}_{2} \mathrm{O}$ between the crystals and solution. March 25, 1938.] 